\title{
FLAVONOIDS FROM THE ROOTS OF DIOCLEA REFLEXA (HOOK F.)
}

\author{
Abdulkabir O. Oladimeji ${ }^{1,2}$, Ibrahim A. Oladosu ${ }^{1 *}$, Mohammad S. Ali ${ }^{3}$ and Zeeshan Ahmed ${ }^{3}$ \\ ${ }^{1}$ Organic and Medicinal Unit, Department of Chemistry, University of Ibadan, Nigeria \\ ${ }^{2}$ Department of Chemical and Geological Sciences, Al-Hikmah University, Ilorin, Nigeria \\ ${ }^{3}$ International Centre for Chemical and Biological Sciences (ICCBS), Karachi, Pakistan
}

(Received May 1, 2014; revised June 7, 2015)

ABSTRACT. Reflevone (1), a new flavone, together with, mearnsetin (2), 7,4'-dihydroxyflavone (3) and two known phytosterols, $\beta$-sitosterol (4) and stigmasterol (5) were isolated from ethanol soluble part of the roots of Dioclea reflexa (Hook F.). Their structures were elucidated by analysis of spectroscopic data involving $1 \mathrm{D}$ and $2 \mathrm{D}$ NMR, MS, IR and UV experiments. The crude roots extract showed significant activity with $\mathrm{IC}_{50}=5.18 \mu \mathrm{g} / \mathrm{mL}$ against the prostate cancer cell line.

KEY WORDS: Phytochemical analysis, Dioclea reflexa, Fabaceae, Cytotoxic activity, Flavonoid

\section{INTRODUCTION}

Dioclea (Leguminosae-Fabacea) is a small genus containing 40 species, widely distributed in Africa and South America [1]. The pharmacological activities of this genius include anticonvulsant, anxiolytic [2], antioxidant [3], antiarrhythmogenic [4], immunodulatory [5], analgesic and central antinociceptive effects [6], which have been identified with Dioclea plants. Dioclea reflexa (Hook F.) is a woody climber, which produces flowers and pods on long ropelike stems that hang from the forest canopy. It is known as 'Agbaarin' in Western Nigeria. The stem extract of this species is used by the local populace as an anti-tuberculosis (TB), and antiinflammatory agents; and also in the treatment of rheumatism and itching [7, 8]. Previous studies of the seed have led to the isolation of dioclimidazole and two steroids: taraxasterol and stigmasterol $[7,9]$. In our earlier work on the root of $D$. reflexa, we characterized 15 volatile compounds comprising monoterpenes and diterpenes [8]. Although, several secondary metabolites have been isolated from the seeds $[7,8]$ of $D$. reflexa, none have been reported from the roots of this species. In our search for the active constituents of $D$. reflexa, we hereby report an investigation of the cytotoxic activity of the crude extracts of leaves, stems and roots of $D$. reflexa against prostate cancer cell (PC-3). This led to the isolation and characterization of a new flavone, reflevone (1), together with mearnsetin (2), 7,4'-dihydroxyflavone (3), $\beta$-sitosterol (4) and stigmasterol (5) from roots extract. This is the first reported isolation of compounds 1-3 from this species.<smiles>[R5]c1cc(-c2oc3cc(O)cc([R2])c3c(=O)c2[R6])cc([R5])c1[R6]</smiles>

*Corresponding author. E-mail: dosufau@gmail.com 
Abdulkabir O. Oladimeji et al.

\begin{tabular}{cccccc} 
Compound & $\mathrm{R}_{1}$ & $\mathrm{R}_{2}$ & $\mathrm{R}_{3}$ & $\mathrm{R}_{4}$ & $\mathrm{R}_{5}$ \\
$\mathbf{1}$ & $\mathrm{H}$ & $\mathrm{H}$ & $\mathrm{OH}$ & $\mathrm{CH}_{3}$ & $\mathrm{OH}$ \\
$\mathbf{2}$ & $\mathrm{OH}$ & $\mathrm{OH}$ & $\mathrm{OH}$ & $\mathrm{CH}_{3}$ & $\mathrm{OH}$ \\
$\mathbf{3}$ & $\mathrm{H}$ & $\mathrm{H}$ & $\mathrm{H}$ & $\mathrm{H}$ & $\mathrm{H}$ \\
& \multicolumn{4}{l}{ EXPERIMENTAL } & \\
\end{tabular}

General experimental procedures

The ${ }^{1} \mathrm{H}-\mathrm{NMR}$ spectra $(\delta \mathrm{ppm}, \mathrm{J}$ in $\mathrm{Hz}$ ) were recorded in deuteriated acetone or methanol on a Bruker AM-400 spectrometer (400 MHz), while ${ }^{13} \mathrm{C}$-NMR spectra were recorded on the same instrument using the same solvent at $100 \mathrm{MHz}$. IR and UV were recorded using a JASCO 302A and SHIMADZU UV-240 spectrometers respectively. HR-EIMS were carried out using MAT 95XP spectrometer. For the detection of samples on TLC plates, ceric sulfate spray reagent and UV light were used. TLC was carried out to check the purity of samples on pre-coated Merck silica gel $\mathrm{F}_{254}$ aluminium sheets $(0.25 \mathrm{~mm}$ thickness). Column chromatography was performed on silica gel (70-230 mesh) and Sephadex LH-20 (Fluka 25-100 mm). Melting points were determined on a Buchi $510-\mathrm{K}$ melting point apparatus and were uncorrected. Enzyme-linked immonosorbent assays were recorded on Spectra Max plus 384, Molecular Devices, CA, USA, reader.

\section{Plant material}

The whole plant of Dioclea reflexa was collected from a farm land at Eruwa in Ibarapa East Local Government area of Oyo state, Nigeria, in May, 2011, and authenticated by Mr Bolu Ajayi of Herbarium Section, Plant Biology Department, University of Ilorin, Nigeria and a voucher specimen (UIL-0027) was deposited at the herbarium of the University.

\section{Extraction and isolation}

The air-dried and powdered roots of $D$. reflexa $(1 \mathrm{~kg})$ were extracted with $5 \mathrm{~L}$ of ethanol at room temperature for two weeks. Evaporation of the solvent under vaccuo yielded crude root ethanol extract $(85 \mathrm{~g})$. The same extraction procedure was adopted for the leaves and stem ethanol extracts. These extracts were first subjected to preliminary anticancer assay. The crude root ethanol extract was then subjected to silica gel column chromatography, eluted with gradient of n-hexane, dichloromethane, ethyl acetate and methanol in increasing polarity. The 332 fractions (100 mL/vial) collected were combined according to TLC profile.

The combined fractions 205-241 (1.2 g), eluted with n-hexane/EtOAc $\left(\mathrm{R}_{\mathrm{f}} 55: 45\right)$ was further purified by column chromatography using n-hexane and EtOAc gradient to give $\mathbf{1}(7 \mathrm{mg})$, in addition to four semi-pure sub-fractions labeled $\mathrm{F}_{1}-\mathrm{F}_{4}$.

Sub-fraction $F_{1}(262 \mathrm{mg})$ was subjected to repeated column chromatography in Sephadex LH-20 using $100 \% \mathrm{MeOH}$ elution, which led to the isolation of compound $2(5 \mathrm{mg})$ as yellow powder. Similarly, fraction labelled $F_{2}$ yielded compound $3(5 \mathrm{mg})$. Compounds $4(9.0 \mathrm{mg})$ and $5(4.8 \mathrm{mg})$ were also obtained from repeated column chromatography over silica gel and Sephadex of sub-fractions $\mathrm{F}_{3}$ and $\mathrm{F}_{4}$ respectively.

Physical and spectral data of the compound (1)

7-Hydroxy-2-(3,5-dihydroxy-4-methoxyphenyl)-4H-chromen-4-one, $\mathrm{C}_{16} \mathrm{H}_{12} \mathrm{O}_{6}$; yellow crystals, mp $220{ }^{\circ} \mathrm{C}$. UV $\lambda_{\max } \mathrm{nm}(\log \varepsilon)=212(1.45), 311(0.9)$; IR (KBr): $3377(\mathrm{OH}), 1676(\mathrm{C}=\mathrm{O})$, $1570(\mathrm{C}=\mathrm{C}) \mathrm{cm}^{-1}$; EIMS m/z (relative intensity \%): 53 (48), 77 (22), 108 (20), 121 (40), 137 (40), 149 (29), 164 (8), 200 (8), 229 (100), 257 (96), 300 (89). HREIMS = 300.0621 (calculated $=300.2700$ for $\left.\mathrm{C}_{16} \mathrm{H}_{12} \mathrm{O}_{6}\right) .{ }^{1} \mathrm{H}-\mathrm{NMR}\left(\mathrm{CD}_{3} \mathrm{COCD}_{3}, 400 \mathrm{MHz}\right)($ Table 2$) .{ }^{13} \mathrm{C}-\mathrm{NMR}\left(\mathrm{CD}_{3} \mathrm{COCD}_{3}\right.$, $100 \mathrm{MHz}$ ) (Table 2). 
Physical and spectral data of the compound (2)

3,5,7-Trihydroxy-2-(3,5-dihydroxy-4-methoxyphenyl)-4H-chromen-4-one, $\mathrm{C}_{16} \mathrm{H}_{12} \mathrm{O}_{8}$; yellow powder, mp 208-210 ${ }^{\circ} \mathrm{C}$. UV $\lambda_{\max } \mathrm{nm}(\log \varepsilon)=212$ (1.268), 262 (0.749), 365 (0.845); IR (KBr): $1676(\mathrm{C}=\mathrm{O}$ ketone), 1659 (ring $\mathrm{C}=\mathrm{C}), 1597,1459,1452,849 \mathrm{~cm}^{-1}$; EIMS $\mathrm{m} / \mathrm{z}$ (relative intensity \%): 332.1 (91), $317\left(\mathrm{M}^{+}, 100\right), 289$ (20), 261 (48), 233 (11), 205 (10), 177 (6), 153 (20), 108 (12), 77 (32). HREIMS = 332.0574 (calcd. 332.25287 for $\left.\mathrm{C}_{16} \mathrm{H}_{12} \mathrm{O}_{8}\right) .{ }^{1} \mathrm{H}-\mathrm{NMR}\left(\mathrm{CD}_{3} \mathrm{COCD}_{3}\right.$, $400 \mathrm{MHz}$ ) (Table 3). ${ }^{13} \mathrm{C}-\mathrm{NMR}\left(\mathrm{CD}_{3} \mathrm{COCD}_{3}, 100 \mathrm{MHz}\right)$ (Table 3).

\section{Physical and spectral data of the compound (3)}

7-Hydroxy-2-(4-hydroxyphenyl)-4H-chromen-4-one, $\mathrm{C}_{15} \mathrm{H}_{10} \mathrm{O}_{4}$; yellow powder, mp $315{ }^{\circ} \mathrm{C}$. UV $\lambda_{\max } \mathrm{nm}(\log \varepsilon)=213$ (1.627), 230 (1.362), 328 (1.677); IR (KBr) = 3619 (Ar-OH), 1676 (ketones $\mathrm{C}=\mathrm{O}$ ), 1649 (ring $\mathrm{C}=\mathrm{C}) \mathrm{cm}^{-1}$; EIMS m/z (relative intensity \%): $254.2\left(\mathrm{M}^{+}, 100\right), 237$ (5.5), 226 (41), 136 (9), 137 (40), 118 (24), 86 (39), HREIMS = 254.0567 (calcd. 254.24425 for $\left.\mathrm{C}_{15} \mathrm{H}_{10} \mathrm{O}_{4}\right) .{ }^{1} \mathrm{H}-\mathrm{NMR}\left(\mathrm{CD}_{3} \mathrm{OD}, 400 \mathrm{MHz}\right)$ (Table 3). ${ }^{13} \mathrm{C}-\mathrm{NMR}\left(\mathrm{CD}_{3} \mathrm{OD}, 100 \mathrm{MHz}\right)$ (Table 3).

\section{In vitro cytotoxicity assay}

The cytotoxic activity against Prostrate Cancer (PC-3) cells using test extract was performed in 96-well flat-bottomed micro plates by employing 3-[4,5-dimethylthiazole-2-yl]-2,5-diphenyltetrazolium bromide (MTT) colorimetric assay [10]. The PC-3 cells were grown in Dulbecco's Modified Eagle Medium, supplemented with 5\% fetal bovine serum (FBS) and antibiotics (100 $\mu \mathrm{g} / \mathrm{mL}$ of penicillin and $100 \mu \mathrm{g} / \mathrm{mL}$ of streptomycin) under a $5 \% \mathrm{CO}_{2}$ humidified atmosphere at $37^{\circ} \mathrm{C}$ incubation. Cells culture with a density of $1 \times 10^{5}$ cells $/ \mathrm{mL}$ were exposed to plant extract dissolved in DMSO at various concentrations of 1-30 $\mu \mathrm{M}$. After $48 \mathrm{~h}$, cells were washed 3 times with FBS, and then $200 \mu \mathrm{L}$ of $0.5 \mathrm{mg} / \mathrm{mL}$ MTT solution in FBS was added and incubated for 4 h. Finally, $100 \mu \mathrm{L}$ of DMSO was added to each well. In the experiment, Doxorubicin was used as positive control. The optical density was measured spectrophotometrically at $570 \mathrm{~nm}$ in an enzyme-linked immonosorbent assay reader (Spectra Max plus 384, Molecular Devices, CA, USA). The $50 \%$ inhibition concentration $\left(\mathrm{IC}_{50}\right)$ was calculated as the compound concentration required to reduce MTT signals by $50 \%$ compared with untreated control cultures.

\section{RESULTS AND DISCUSSION}

The $\mathrm{IC}_{50}$ values of various parts extract of $D$. reflexa when tested against PC-3 cell lines are presented in Table 1 . The roots extract showed cytotoxic activity against the cell lines $\left(\mathrm{IC}_{50} 5.18\right.$ $\mu \mathrm{g} / \mathrm{mL})$ when compared to the positive control, doxorubicin $(2.8 \mu \mathrm{g} / \mathrm{mL})$. This strong cytotoxic activity prompted further investigation of the roots ethanol extract of $D$. reflexa. The roots extract was then subjected to repeated column chromatography which yielded compound $\mathbf{1}$.

Table 1. Results of anticancer assay of various parts of D. reflexa extracts.

\begin{tabular}{|l|c|}
\hline Extracts & $1_{50} \pm \mathrm{SEM}(\mu \mathrm{g} / \mathrm{mL}) \mathrm{PC} 3$ \\
\hline Leaves & NA \\
\hline Stems & $11.42 \pm 0.7$ \\
\hline Roots & $5.18 \pm 0.3$ \\
\hline Doxorubicin & $2.8 \pm 0.12$ \\
\hline
\end{tabular}

PC3, human prostate cancer cell; NA, not active; SEM, standard error of mean.

Compound 1 was isolated as a yellow powder. The molecular formula was established as $\mathrm{C}_{16} \mathrm{H}_{12} \mathrm{O}_{6}$ (300.0621) corresponding to 11 units of unsaturation based on the HREIMS, ${ }^{13} \mathrm{C}$ and DEPT NMR data (Table 2). The UV spectrum of 1 showed maxima at $\lambda_{\max }(\log \varepsilon) \mathrm{nm} 212(1.45)$ 
and 311(0.9) similar to those of flavones skeleton with two absorption bands. The IR spectrum suggested the presence of hydroxyl $\left(3377 \mathrm{~cm}^{-1}\right)$, conjugated carbonyl $\left(1776 \mathrm{~cm}^{-1}\right)$ and aromatic system $\left(1570 \mathrm{~cm}^{-1}\right)$.

Table $2 .{ }^{1} \mathrm{H}$ and ${ }^{13} \mathrm{C}$ NMR spectra data of compound 1 ( $\delta$ values; $400 \mathrm{MHz}$ and $100 \mathrm{MHz}$, acetone- $\left.\mathrm{d}_{6}\right)$.

\begin{tabular}{|c|l|c|c|r|}
\hline Position & \multicolumn{1}{|c|}{$\mathrm{H} \delta($ integration, multiplicity, J in $\mathrm{Hz})$} & ${ }^{13} \mathrm{C}$ & $\mathrm{DEPT}$ & HMBC \\
\hline 2 & - & 163.30 & $\mathrm{C}$ & \\
\hline 3 & $6.54(1 \mathrm{H}, \mathrm{s})$ & 107.03 & $\mathrm{CH}$ & $\mathrm{C}-2, \mathrm{C}-4, \mathrm{C}-10, \mathrm{C}-1^{\prime}$ \\
\hline 4 & - & 177.15 & $\mathrm{C}$ & \\
\hline 5 & $7.95(1 \mathrm{H}, \mathrm{d}, \mathrm{J}=8.8 \mathrm{~Hz})$ & 127.66 & $\mathrm{CH}$ & $\mathrm{C}-4, \mathrm{C}-7, \mathrm{C}-8, \mathrm{C}-9$ \\
\hline 6 & $6.97(1 \mathrm{H}, \mathrm{dd}, \mathrm{J}=2.4,8.8 \mathrm{~Hz})$ & 115.43 & $\mathrm{CH}$ & $\mathrm{C}-8, \mathrm{C}-10$ \\
\hline 7 & $9.64(1 \mathrm{H}, \mathrm{br} \mathrm{s}, \mathrm{OH})$ & 163.30 & $\mathrm{C}$ & \\
\hline 8 & $7.02(1 \mathrm{H}, \mathrm{d}, \mathrm{J}=2.4 \mathrm{~Hz})$ & 103.47 & $\mathrm{CH}$ & $\mathrm{C}-6, \mathrm{C}-7, \mathrm{C}-9, \mathrm{C}-10$ \\
\hline 9 & - & 158.74 & $\mathrm{C}$ & \\
\hline 10 & - & 117.95 & $\mathrm{C}$ & \\
\hline $1^{\prime}$ & - & 128.26 & $\mathrm{C}$ & \\
\hline $2^{\prime} / 6^{\prime}$ & $7.07(1 \mathrm{H}, \mathrm{s})$ & 106.58 & $\mathrm{CH}$ & $\mathrm{C}-2, \mathrm{C}-1^{\prime}, \mathrm{C}-3^{\prime}, \mathrm{C}-4^{\prime}$ \\
\hline $3^{\prime} 5^{\prime}$ & $8.48(\mathrm{~s}, \mathrm{OH})$ & 151.83 & $\mathrm{C}$ & \\
\hline $4^{\prime}$ & - & 139.00 & $\mathrm{C}$ & \\
\hline $\mathrm{OCH}_{3}$ & $3.88(3 \mathrm{H}, \mathrm{s})$ & 60.74 & $\mathrm{CH}$ & $\mathrm{C}_{3} 4^{\prime}$ \\
\hline
\end{tabular}

The analysis of proton NMR spectrum of 1 revealed the presence of one methoxy $\left[\delta_{\mathrm{H}} 3.88\right.$ $\left.(\mathrm{s}) ; \delta_{\mathrm{C}} 60.7\right]$, one meta-coupled [ $\left.\delta_{\mathrm{H}} 7.02,1 \mathrm{H}, \mathrm{d}, J=2.4 \mathrm{~Hz}\right]$, one ortho-coupled $\left[\delta_{\mathrm{H}} 7.95,1 \mathrm{H}, \mathrm{d}\right.$, $J=8.8 \mathrm{~Hz}]$, two supposed meta-coupled but appeared as singlet each because they are symmetrical $\left[\delta_{\mathrm{H}} 7.07,2 \times 1 \mathrm{H}, \mathrm{s}\right]$ and one double-doublet ortho-meta-coupled aromatic protons $\left[\delta_{\mathrm{H}} 6.97,1 \mathrm{H}, \mathrm{dd}, J=2.4\right.$ and $\left.8.8 \mathrm{~Hz}\right]$, three phenolic hydroxyl groups of which two are symmetrical $\left[\delta_{\mathrm{H}} 8.48,8.48,9.64(1 \mathrm{H}\right.$ each, br s) $]$, and an olefinic hydrogen at $\delta_{\mathrm{H}} 6.54,1 \mathrm{H}, \mathrm{s}$.

The ${ }^{13} \mathrm{C}-\mathrm{NMR}$ (Table 2), DEPT and HMBC spectra showed resonances for all 16 carbons comprising one methoxy, six methine and nine quartenary carbons. The most downfield shifted peak at $\delta_{\mathrm{C}} 177.15$ was assigned to carbonyl group (C-4). Two peaks at $\delta_{\mathrm{C}} 106.58$ and $\delta_{\mathrm{C}} 151.83$ showed double intensities and were assigned to $\mathrm{C}-2^{\prime} / 6^{\prime}$ and $\mathrm{C}-3^{\prime} / 5^{\prime}$, respectively $[11,12]$. The HMBC spectrum of 1 showed cross-peaks from H-2' to C-3', C-4', and C-2; from H-3 to C-4, $\mathrm{C}-2$ and $\mathrm{C}-1^{\prime}$ confirming the assignments for $\mathrm{C}-2, \mathrm{H} 2^{\prime} / 6^{\prime}$ and the B-ring. In addition, the methoxy at $\delta_{\mathrm{H}} 3.88$ showed correlation with carbon resonance at $\delta_{\mathrm{C}} 139.0$ on the HMBC spectrum and was assigned C-4' (Figure 1).

Furthermore, the ${ }^{1} \mathrm{H}-{ }^{1} \mathrm{H}$ COSY spectrum demonstrated correlations of $\mathrm{H}-5$ to $\mathrm{H}-6$ (Figure 1). The spectral data were in accordance with reported data on flavonoids of 7-hydroxy A-ring [11, 12].

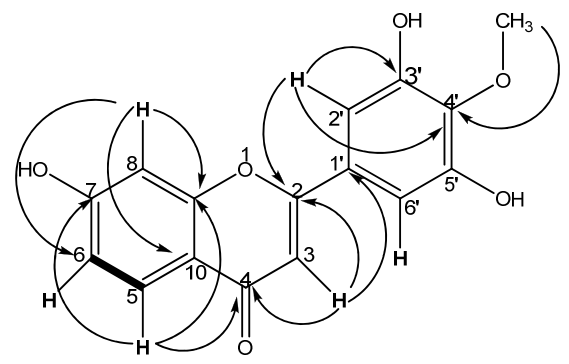

Figure 1. HMBC and COSY connectivities of 1. Key COSY $(-)$ and $\operatorname{HMBC}(\rightarrow)$. 
The $2 \mathrm{H}$ singlet at $\delta 7.07,2 \mathrm{H}$ broad singlet at $\delta 8.48$ and $3 \mathrm{H}$ singlet of methoxy at $\delta 3.88$ in ring $\mathrm{B}$ were assigned to $\mathrm{H}-2^{\prime} / 6^{\prime}, \mathrm{OH}-3^{\prime} / 5^{\prime}$ and $\mathrm{H}^{\prime} 4^{\prime}$, respectively; this suggested a $3^{\prime}, 4^{\prime}, 5^{\prime}$ trioxygenated symmetrical substituted B-ring, typical of mearnsetin B-ring [13]. In HMBC, C-4 showed long-range connectivity to the ${ }^{1} \mathrm{H}$ peak at $7.95 \mathrm{ppm}$ which was directly attached to the ${ }^{13} \mathrm{C}$ peak at $127.66 \mathrm{ppm}$ (HSQC spectrum) and was assigned as C-5. In addition, the ${ }^{1} \mathrm{H}$ at 7.95 ppm showed long-range coupling to ${ }^{13} \mathrm{C}$ signals at $163.3 \mathrm{ppm}$ and $158.74 \mathrm{ppm}$, these were assigned as C-7 and C-9, respectively. The pronounced upfield shift of ${ }^{13} \mathrm{C}$ peak at $163.3 \mathrm{ppm}$ further supported the presence of a hydroxyl at C-7. The COSY spectrum as well as the HMQC spectrum confirmed the proposed structure (Figure 1). The complete assignments of the ${ }^{1} \mathrm{H}$ and ${ }^{13} \mathrm{C}$-NMR data are listed in Table 2 . These observations suggested that compound $\mathbf{1}$ is a $7,3^{\prime}, 5^{\prime}-$ trihydroxy-4'-methoxyflavone. Extensive literature search further revealed that compound $\mathbf{1}$ is new and has not been reported in the chemical literature, hence it was given the trivial name reflevone.<smiles></smiles><smiles>CC1(C)C=CC(=O)C1C=O</smiles>

$\mathbf{m} / \mathbf{z}=137[\mathbf{A}+\mathbf{1}]$
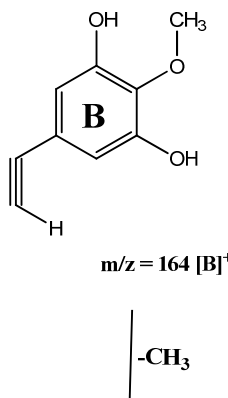

Chemical Formula: $\mathrm{C}_{8} \mathrm{H}_{5} \mathrm{O}_{3}{ }^{-}$<smiles>[O-]c1c(O)cc(/C=C\c2ccccc2)cc1O</smiles>

$\mathbf{m} / \mathbf{z}=149$

Scheme 1. Fragmentation pattern for compound $\mathbf{1}$.

The retro-Diels-Alder fragments of ring $\mathrm{C}$ led to diagnostic peaks at $\mathrm{m} / \mathrm{z} 137$ and 164 , supporting the presence of one hydroxyl in ring A, a methoxy and two hydroxyls in ring B 
(Scheme 1). Another diagnostic fragment at $\mathrm{m} / \mathrm{z} 149\left(\mathrm{C}_{8} \mathrm{H}_{5} \mathrm{O}_{3}\right)$ indicated methoxy moiety at C-4' which was demethylated (Scheme 1). Other significant peaks in addition to molecular ion at $\mathrm{m} / \mathrm{z}$ 300.1 are $285\left[\mathrm{M}^{+}-\mathrm{CH}_{3}\right], 257,229$ and 121.

Table 3. ${ }^{1} \mathrm{H}(400 \mathrm{MHz})$ and ${ }^{13} \mathrm{C}(100 \mathrm{MHz})$ NMR Spectra data of 2 (in $\mathrm{CD}_{3} \mathrm{COCD}_{3}$ ) and 3 (in $\left.\mathrm{CD}_{3} \mathrm{OD}\right)$.

\begin{tabular}{|l|l|l|l|l|l|l|}
\hline & & 2 & & 3 & \\
\hline Position & $\begin{array}{c}\text { I } \mathrm{H} \delta \text { (integration, } \\
\text { multiplicity, J in Hz) }\end{array}$ & ${ }^{13} \mathrm{C}$ & $\mathrm{DEPT}$ & $\begin{array}{c}\mathrm{H} \delta \text { (integration, } \\
\text { multiplicity, J in Hz) }\end{array}$ & ${ }^{13} \mathrm{C}$ & DEPT \\
\hline 2 & - & 146.16 & $\mathrm{C}$ & - & 166.02 & $\mathrm{C}$ \\
\hline 3 & - & 137.52 & $\mathrm{C}$ & - & 105.13 & $\mathrm{CH}$ \\
\hline 4 & - & 176.73 & $\mathrm{C}$ & - & 180.30 & $\mathrm{C}$ \\
\hline 5 & $12.10(1 \mathrm{H}, \mathrm{s}, \mathrm{OH})$ & 162.3 & $\mathrm{C}$ & $7.96(1 \mathrm{H}, \mathrm{d}, \mathrm{J}=8.8)$ & 127.75 & $\mathrm{CH}$ \\
\hline 6 & $6.26(1 \mathrm{H}, \mathrm{d}, \mathrm{J}=2 \mathrm{~Hz})$ & 99.18 & $\mathrm{CH}$ & $6.91(1 \mathrm{H}, \mathrm{dd}, \mathrm{J}=2,8.8)$ & 116.32 & $\mathrm{CH}$ \\
\hline 7 & - & 165.14 & $\mathrm{C}$ & - & 165.00 & $\mathrm{C}$ \\
\hline 8 & $6.52(1 \mathrm{H}, \mathrm{d}, \mathrm{J}=2 \mathrm{~Hz})$ & 94.44 & $\mathrm{CH}$ & $6.97(1 \mathrm{H}, \mathrm{d}, \mathrm{J}=2)$ & 103.50 & $\mathrm{CH}$ \\
\hline 9 & - & 157.79 & $\mathrm{C}$ & - & 159.50 & $\mathrm{C}$ \\
\hline 10 & - & 104.17 & $\mathrm{C}$ & - & 114.30 & $\mathrm{C}$ \\
\hline $1^{\prime}$ & - & 127.31 & $\mathrm{C}$ & - & 123.50 & $\mathrm{C}$ \\
\hline $2^{\prime} / 6^{\prime}$ & $7.38(2 \mathrm{H}, \mathrm{s})$ & 108.31 & $\mathrm{CH}$ & $7.86(2 \mathrm{H}, \mathrm{dt}, \mathrm{J}=2.8,9.2)$ & 129.39 & $\mathrm{CH}$ \\
\hline $3^{\prime} / 5^{\prime}$ & $8.36(2 \mathrm{H}, \mathrm{s}, \mathrm{OH})$ & 151.31 & $\mathrm{C}$ & $6.91(2 \mathrm{H}, \mathrm{m}, \mathrm{J}=2.4,8.8)$ & 117.01 & $\mathrm{CH}$ \\
\hline $4^{\prime}$ & - & 138.02 & $\mathrm{C}$ & - & 162.50 & $\mathrm{C}$ \\
\hline $\mathrm{OCH}_{3}$ & $3.88(3 \mathrm{H}, \mathrm{s})$ & 60.69 & $\mathrm{CH}$ & - & & \\
\hline
\end{tabular}

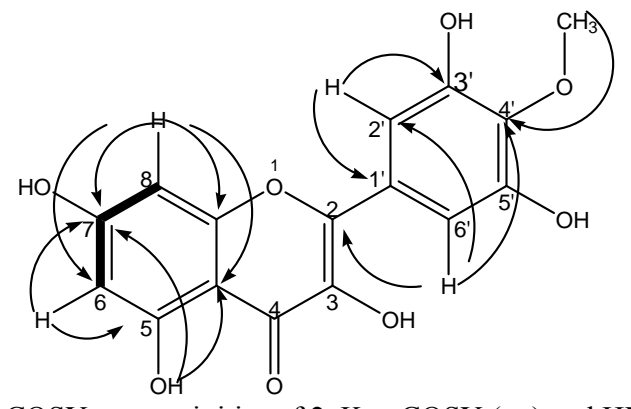

Figure 2. HMBC and COSY connectivities of 2. Key COSY $(-)$ and $\operatorname{HMBC}(\rightarrow)$.

Compound 2, obtained as a yellow powder was assigned the molecular formula $\mathrm{C}_{16} \mathrm{H}_{12} \mathrm{O}_{8}$ with molecular ion peak at $\mathrm{m} / \mathrm{z} 332$ from HR-EIMS and supported by its NMR spectra data (Table 3). The UV spectrum in methanol showed maximum absorptions at 365, 260 and 212 $\mathrm{nm}$. The ${ }^{1} \mathrm{H}-\mathrm{NMR}$ spectrum (Figure 2) showed two meta coupled $1 \mathrm{H}$ doublets at $6.26(\mathrm{~J}=2 \mathrm{~Hz})$ and $6.52(\mathrm{~J}=2 \mathrm{~Hz})$ assigned to $\mathrm{H}-6$ and $\mathrm{H}-8$ respectively corresponding to $\delta \mathrm{c} 99.18 \mathrm{ppm}$ and $\delta \mathrm{c}$ $94.44 \mathrm{ppm}$ respectively in the HSQC spectrum, characterised the H-6 and H-8 of a flavonoid 5,7-dihydroxyl A-ring [14]. The ${ }^{13} \mathrm{C}$-NMR spectrum revealed all the sixteen carbons which were deduced as one methoxyl, four methines and eleven quartenary carbons. The broad singlet ${ }^{1} \mathrm{H}$ peaks at $\delta_{\mathrm{H}} 8.36 \mathrm{ppm}$ which was not directly attached to any carbon in HSQC, was assigned to $3^{\prime} / 5^{\prime}-\mathrm{OH}$. In the ${ }^{1} \mathrm{H}-\mathrm{NMR}$ spectrum, $3 \mathrm{H}$ singlet at $\delta_{\mathrm{H}} 3.88$ revealing a methoxyl group correlated with the carbon resonance at $138.02\left(\mathrm{C}-4^{\prime}\right)$ on the $\mathrm{HMBC}$ spectrum. The $2 \mathrm{H}$ singlets at $\delta_{\mathrm{H}} 7.38$ was attributed to the one proton each at $2^{\prime}$ and $6^{\prime}$ positions of $3^{\prime}, 4^{\prime}, 5^{\prime}$ tri-O-substituted $\mathrm{B}$ ring. Long-range COSY spectrum in conjuction with the $\mathrm{HMBC}$ spectrum allowed the assignments of $\mathrm{H}-6$ and $\mathrm{H}-8$ (Figure 2). A singlet at $\delta_{\mathrm{H}} 12.1$ corresponding to ${ }^{13} \mathrm{C}$ peak at $\delta_{\mathrm{C}} 162.3 \mathrm{ppm}$ in $\mathrm{HSQC}$, implied the presence of an $\mathrm{OH}$ at $\mathrm{C}-5$, since $\mathrm{H}$-bonding with the $\mathrm{C}=\mathrm{O}(\mathrm{C}-4)$ causes this 
type of substituted flavonoid to give signal between 159.8 and 162.3 . Also, the signals for C-5 unsubstituted flavonoids are usually found between 106.9 and 127.75 [12]. Thus compound 2 was identified as 3,5,7,3',5'-pentahydroxy-4-methoxyflavone (mearnsetin) by comparison of it spectra data with the literature [13, 14].

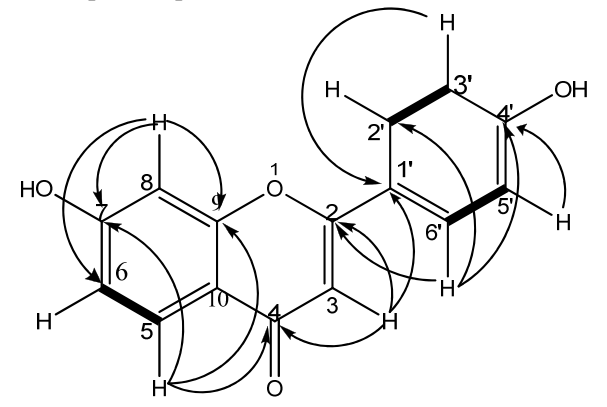

Figure 3. HMBC connectivities of 3. Keys: COSY $(-)$ and $\operatorname{HMBC~}(\rightarrow)$.

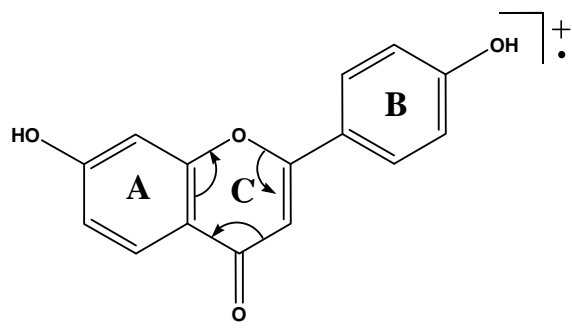

RDA
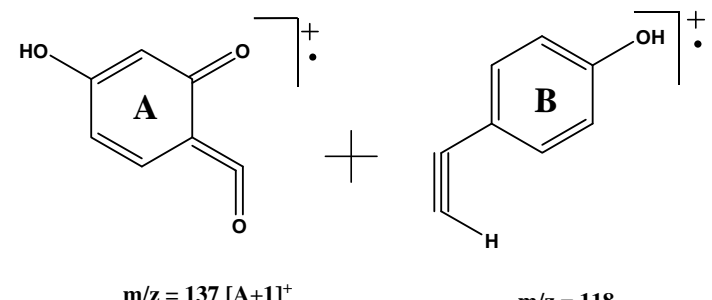

Scheme 2. Fragmentation pattern of compound 3

The ${ }^{1} \mathrm{H}-\mathrm{NMR}$ spectrum of compound 3 displayed two $1 \mathrm{H}$ doublets at $\delta 6.97$ and $\delta 7.96$ assigned to $\mathrm{H}-8$ and $\mathrm{H}-5$ respectively. A $3 \mathrm{H}$ multiplet at $\delta 6.91$ was assigned to $\mathrm{H}-6$ and two equivalent aromatic protons at $\mathrm{H}-3^{\prime} / 5^{\prime}$. The ${ }^{13} \mathrm{C}$ NMR, DEPT and HMBC experiments showed signals for 15 carbons which were deduced as: seven quaternary and eight methine carbons. The 
various connectivities in the molecule were determined through HMBC and COSY experiments, which concluded the position of $\mathrm{OH}$ at $\mathrm{C}-7$ and $\mathrm{C}-4$ ' (Figure 3). The molecular formular of compound $3\left(\mathrm{C}_{15} \mathrm{H}_{10} \mathrm{O}_{4}\right)$ was deduced from the high resolution electron impact mass spectrum (HR-EIMS). The Retro-Diels-Alder (RDA) fragmentation of the heterocyclic ring produced ions at $\mathrm{m} / \mathrm{z} 137[\mathrm{~A}+1]^{+}$and $\mathrm{m} / \mathrm{z} 118[\mathrm{~B}]^{+}$(Scheme 2) which indicated that A-ring and B-ring possessed $\mathrm{OH}$ substituent each. Other significant peaks in addition to the molecular ion at $\mathrm{m} / \mathrm{z}$ 254 are $237[\mathrm{M}-\mathrm{OH}]^{+}, 226\left[\mathrm{C}_{14} \mathrm{H}_{10} \mathrm{O}_{3}\right], 137\left[\mathrm{C}_{7} \mathrm{H}_{5} \mathrm{O}_{3}\right]$ and $108\left[\mathrm{C}_{6} \mathrm{H}_{4} \mathrm{O}_{2}\right]$. The comparison of the corresponding UV, EIMS, ${ }^{1} \mathrm{H}$ and ${ }^{13} \mathrm{C}$ NMR data (Table 3) with those reported in literature [11, 15-17] led to its identification as 7,4'-dihydroxyflavone. Compounds $\mathbf{4}$ and $\mathbf{5}$ were identified as $\beta$-sitosterol and stigmasterol respectively [18]. This is the first reported isolation of compounds 1-3 from this species.

In conclusion, the present study has shown that roots extracts of $D$. reflexa could be a lead in discovery of anti-cancer drug as demonstrated by its cytotoxic effect. Purification of the roots extracts led to the isolation of a new flavone compound and four others. Further studies are suggested on screening the isolated compounds against PC-3 cell lines, particularly the new compound, reflevone.

\section{ACKNOWLEDGMENTS}

The authors are grateful to Third World Academy of Science (TWAS) and International Centre for Chemical and Biological sciences (ICCBS) for fellowship support to A.O. Oladimeji. We are indebted to Mr. Bolu Ajayi of Herbarium Section, Plant Biology Department, University of Ilorin for his assistance in the identification and authentication of the plant.

\section{REFERENCES}

1. Burkill, H.M. The Useful Plants of West Tropical Africa, 2nd ed., Royal Botanic Gardens: $\mathrm{UK} ; 1984$;

2. De Almeida, E.R.; Xavier, H.S.; Chaves, T.M.; Couto, G.B.L.; Aragao-Neto, A.C.; Silva, A.R.; Da Silva, L.L.S. Int. J. App. Res. Nat. Prod. 2010, $2,44$.

3. Barreiros, A.L.B.S.; David, J.P.; Queiroz, L.P.; David, J.M. Phytochemistry 2000, 55, 805.

4. Vianna, H.R.; Cortes, S.F.; Ferreira, A.J.; Carpettini, L.S.A.; Schnitt, M.; Almeida, A.P.; Massensini, A.R.; Lemos, V.S. Planta Med. 2006, 72, 300.

5. Alves, C.Q.; Kijjoa, A.; David, J.M.; David, J.P. Planta Med. 2010, 76-P368. DOI:10.551s0030-126466.

6. Almeida, E.R.; Almeida, R.N.; Navairo, D.S.; Bhattacharya, J.; Silva, V.A.; Birnbaum, J.S.P. J. Ethnopharmacol. 2003, 88, 1.

7. Faleye, F.J. J. Pharm. Sci. Innov. 2012, 1, 89.

8. Oladosu, I.A.; Oladimeji, A.O. Elixir Org. Chem. 2012, 45, 7738.

9. Oladosu, I.A.; Echeme, J.O.; Zubair, M.F. Fitoterapia 2006, 77, 571.

10. Mosmann, T. J. Immunol. Methods 1983, 65, 55.

11. Park, Y.; Moon, B.; Lee, E.; Lee, Y.; Yoon, Y.; Ahn, J.; Lim, Y. Magn. Reson. Chem. 2007, 45, 674.

12. Park, Y.; Lee, Y.; Kim, H.; Lee, Y.; Yoon, Y.; Moon, B.; Chong, Y.; Ahn, J.; Shim, Y.; Lim, Y. Bull. Korean Chem. Soc. 2006, 27, 1537.

13. Abbas, F.A.; Al-Massarany, S.M.; Khan, S.; Al-Howiriny, T.A.; Mossa, J.S.; Abdourasheed, E.A. Nat. Prod. Res. 2007, 21, 383.

14. Gluchoff-Fiasson, K.; Fenet, B.; Leclerc, J.; Lussignol, M.; Jay, M. Chem. Pharm. Bull. 2001, 49, 768.

15. Bickoff, E.M.; Livingston, A.L.; Witt, S.C. Phytochemistry 1964, 9, 523.

16. Maxwell, C.A.; Hartwig, U.A.; Joseph, C.M.; Phillips, D.A. Plant Physiol. 1989, 91, 842.

17. Meskuriyen, D.; Cordell, G.A. J. Sci. Soc. Thailand 1988, 14, 24.

18. Ngnokam, D.; Massiot, G.; Nuzillard, J.M.; Tsamo, E. Bull. Chem. Soc. Ethiop. 1994, 8, 15. 